\title{
Segregated Expression of AMPA-Type Glutamate Receptors and Glutamate Transporters Defines Distinct Astrocyte Populations in the Mouse Hippocampus
}

\author{
Katja Matthias, ${ }^{1}$ Frank Kirchhoff, ${ }^{2}$ Gerald Seifert, ${ }^{1}$ Kerstin Hüttmann, ${ }^{1}$ Marina Matyash, ${ }^{3}$ Helmut Kettenmann, ${ }^{3}$ and \\ Christian Steinhäuser ${ }^{1}$ \\ ${ }^{1}$ Experimental Neurobiology, Department of Neurosurgery, University of Bonn, 53105 Bonn, Germany, ${ }^{2}$ Max Planck Institute for Experimental Medicine, \\ 37075 Göttingen, Germany, and ${ }^{3}$ Max Delbrück Center for Molecular Medicine, Cellular Neurosciences, 13092 Berlin, Germany
}

Recent data have suggested the existence of direct signaling pathways between glial cells and neurons. Here we report the coexistence of distinct types of cells expressing astrocyte-specific markers within the hippocampus that display diverse morphological, molecular, and functional profiles. Usage of transgenic mice with GFAP promoter-controlled enhanced green fluorescent protein (EGFP) expression allowed the identification of astroglial cells after fresh isolation or in brain slices. Combining patch-clamp recordings and single-cell reverse transcription-PCR, we distinguished two morphologically distinct types of EGFP-positive cells, one expressing glutamate transporters and the other expressing ionotropic glutamate receptors. None of the EGFP-positive cells coexpressed glutamate receptors and transporters. Subpopulations of glutamate receptor-bearing EGFP-positive cells expressed AN2, the mouse homolog of the rat NG2 proteoglycan or transcripts for excitatory amino acid carrier 1, a neuronal glutamate transporter. Our data demonstrate the presence of distinct, independent populations of cells with astroglial properties in the developing hippocampus that can differently modulate neuronal signaling pathways. The observed heterogeneity of cells with GFAP promoter-regulated EGFP expression and S100 $\beta /$ GFAP immunoreactivity challenges the hitherto accepted definition of astrocytes.

Key words: glial cells; astrocytes; astron; AMPA receptors; glutamate transporters; patch clamp; hippocampus; GFAP promotercontrolled EGFP expression; transgenic mouse; NG2; S100b

\section{Introduction}

Work over the last few years has established that glial cells in vivo express a wide variety of different ion channels and receptors (Steinhäuser and Gallo, 1996; Verkhratsky et al., 1998; Anderson and Swanson, 2000; Verkhratsky and Steinhäuser, 2000). Astrocytes in particular are now regarded as important, direct communication partners of neurons (Porter and McCarthy, 1996; Araque et al., 1998; Bezzi et al., 1998; Kang et al., 1998; Newman and Zahs, 1998; Grosche et al., 1999; for review, see Haydon, 2001). In contrast to neurons, gray matter astrocytes are commonly considered a functionally uniform cell population (Walz, 2000). However, there is increasing evidence that astrocytes in situ are heterogeneous with respect to their antigen profile and functional properties. For example, putative astrocytes with complex and predominantly passive current phenotypes displaying distinct pharmacological and immunocytochemical properties have been distinguished in different gray matter areas (Steinhäuser et al., 1994a; Chvátal et al., 1995; Akopian et al., 1997; Zawar et al., 1999). In the hippocampus, astrocytes with a con-

Received Aug. 14, 2002; revised Dec. 1, 2002; accepted Dec. 11, 2002.

This research was supported by Bundesministerium für Bildung und Forschung (0311469B), Deutsche Forschungsgemeinschaft (SFB-TR3, 515), Volkswagen Foundation (1174871), and Fonds der Chemischen Industrie. We gratefully acknowledge the excellent technical assistance of I. Krahner and thank J. Trotter and A. Wallraff for comments on this manuscript.

Correspondence should be addressed to Dr. Christian Steinhäuser, Experimental Neurobiology, Department of Neurosurgery, University of Bonn, Sigmund-Freud-Strasse 25, 53105 Bonn, Germany. E-mail: Christian.Steinhaeuser@ukb.unibonn.de.

Copyright $\odot 2003$ Society for Neuroscience $\quad 0270-6474 / 03 / 231750-09 \$ 15.00 / 0$ trasting glutamate responsiveness have been described: cells that expressed functional AMPA-type glutamate receptors (GluRs) but lacked glutamate uptake (Seifert and Steinhäuser, 1995; Seifert et al., 1997b; Zhou and Kimelberg, 2001) and cells that possessed significant glutamate transport currents (Bergles and Jahr, 1997, 1998; Zhou and Kimelberg, 2001). In addition, functional properties of astrocytes significantly change during development and in response to brain damage and disease (Verkhratsky and Steinhäuser, 2000).

Here we asked whether this variety reflects different stages of cellular maturation from precursors to more mature cells or rather indicates the existence of distinct astrocyte cell types. Because the human GFAP promoter has been shown to target ectopic reporter gene expression into astrocytes (Brenner and Messing, 1996; Nolte et al., 2001), Tg(GFAP/EGFP) mice were used to enable on-line detection of living astrocytes before their functional analysis. Virtually all of the green fluorescent cells expressed $S 100 \beta$ or GFAP, or both, which are considered as astrocyte-specific markers in gray matter of the CNS. Surprisingly, however, subpopulations of enhanced green fluorescent protein (EGFP)/S100 $\beta$-positive cells coexpressed the proteoglycan AN2/NG2, which has been described as a an oligodendrocyte progenitor marker, and transcripts of excitatory amino acid carrier 1 (EAAC1), a presumed neuronal glutamate transporter. Our data strongly suggest the coexistence of different astroglial cell types in the mouse hippocampus that display distinct morphological, molecular, and functional properties. The observed heterogeneity in cells labeled by GFAP promoter-regulated EGFP 
expression questions the current definition of an astrocyte as a cell with GFAP gene activity.

\section{Materials and Methods}

Preparation of acutely isolated cells and brain slices

Cells were acutely isolated as described previously (Steinhäuser et al., 1994b). $\operatorname{Tg}($ GFAP/EGFP) mice (Nolte et al., 2001) [postnatal day (P) $6-\mathrm{P} 20]$ were anesthetized and decapitated, and the brains were cut into $300-\mu \mathrm{m}$-thick slices. Slice preparation was performed in $\mathrm{Ca}^{2+}$-free, oxygenated solution containing (in $\mathrm{mM}$ ): $90 \mathrm{NaCl}, 3 \mathrm{KCl}, 5 \mathrm{MgSO}_{4}, 1 \mathrm{Na}-$ pyruvate, 10 glucose, $10 \mathrm{HEPES}, 90$ sucrose, $\mathrm{pH} 7.4\left(4^{\circ} \mathrm{C}\right)$. The tissue was then incubated in oxygenated ACSF containing papain $(24 \mathrm{U} / \mathrm{ml})$ and cysteine $(0.24 \mathrm{mg} / \mathrm{ml})(6-20 \mathrm{~min}$, room temperature). After washing, the CA1 region of the hippocampus was dissected. and cells were isolated using Pasteur pipettes or tungsten needles. Acute tissue slices $(150 \mu \mathrm{m}$ thick) for in situ recordings were prepared as reported previously (Steinhäuser et al., 1992). Patches were excised from cells in the CAl stratum radiatum using water immersion infrared optics (Axioskop FS, Zeiss, Oberkochen, Germany).

\section{Electrophysiology and drug application}

Membrane currents were obtained with the patch-clamp technique (room temperature), and the cells were grouped as follows: P6, P9 (P9$12)$, and P18 (P18-20). Signals were filtered (3 or $10 \mathrm{kHz})$ and sampled (10 or $100 \mathrm{kHz}$; EPC 7 or EPC 9, List, HEKA Elektronik, Germany). Recording pipettes were fabricated from borosilicate capillaries (Malsfeld, Hilgenberg, Germany; resistance 4-6 M $\Omega$ ). The standard pipette solution consisted of (in mM): $130 \mathrm{KCl}, 2 \mathrm{MgCl}_{2}, 0.5 \mathrm{CaCl}_{2}, 5$ BAPTA, 10 HEPES, $3 \mathrm{Na}_{2}$-ATP. When cells were analyzed in situ, in most cases $\mathrm{KCl}$ was equimolarly substituted with $\mathrm{KSCN}$ to facilitate the detection of uptake currents. Membrane capacitance $\left(C_{\mathrm{M}}\right)$ and series resistance were compensated $(40-50 \%)$. Standard bath solution consisted of (in mM): $150 \mathrm{NaCl}, 5 \mathrm{KCl}, 2 \mathrm{MgSO}_{4}, 2 \mathrm{CaCl}_{2}, 10$ glucose, 10 HEPES. In some cases, $\mathrm{K}^{+}$currents were suppressed using a solution containing (in mM): 130 $\mathrm{NaCl}, 5 \mathrm{KCl}, 2 \mathrm{MgCl}_{2}, 2 \mathrm{CaCl}_{2}, 10$ D-glucose, 10 HEPES, $0.1 \mathrm{BaCl}_{2}, 4$ 4-aminopyridine (4-AP), 16 tetraethylammonium chloride (TEA). Compounds were from Sigma (Taufkirchen, Germany).

A rapid whole-cell drug application allowed a solution exchange within $1 \mathrm{msec}$ (Seifert and Steinhäuser, 1995). For fast application of agonists to outside-out patches (Colquhoun et al., 1992), a theta glass tube was positioned right-angled with the patch pipette and driven by a piezo translator (P-245.50, Physik Instruments, Waldbronn, Germany). The flow rate through the two barrels was adjusted with a syringe pump. The rise time of solution exchange was $\sim 300 \mu \mathrm{sec}$ (open pipette). The applied solutions were removed by perfusing the recording chamber with high flow rate. For data evaluation, at least three responses were evoked and averaged at each voltage.

\section{Immunohistochemistry and confocal laser scanning microscopy}

$\mathrm{Tg}$ (GFAP/EGFP) mice were anesthetized and perfused with PBS (30 ml) followed by $4 \%$ paraformaldehyde (PFA) ( $50 \mathrm{ml}$ ). Brains were kept in $4 \%$ PFA and washed in PBS, and 40- or 12- $\mu$ m-thick frontal brain sections were cut. Sections were permeabilized with $0.1 \%$ Triton X-100 (TX100) in PBS (20-30 min) and incubated in blocking solution (0.5\% BSA, 1\% horse serum or $10 \%$ fetal calf serum, $4 \%$ or $1 \%$ normal goat serum, $0.01 \%$ TX100 in PBS; $1 \mathrm{hr}$, room temperature). The following antibodies were used: mouse monoclonal (1:500; Hofheim/TS, Chemicon, Germany) or rabbit polyclonal (1:400; Dako, Hamburg, Germany) against GFAP (diluted in PBS with 1\% BSA, $1 \%$ horse serum, $0.01 \%$ TX-100); rabbit polyclonal against $S 100 \beta$ (1:1000 or 1:2500; Swiss Antibodies, Bellinzona, Switzerland); rat monoclonal against AN2 [1:20; DiersFenger et al. (2001)]. Sections were incubated with the primary antibodies $(24 \mathrm{hr})$, and primary antibodies were visualized by application of Oregon Green 514-conjugated goat anti-rabbit IgG (1:2000; Molecular Probes, Eugene, OR), Cy3-conjugated goat anti-rabbit IgG (1:500-1: 100; Dianova, Hamburg, Germany), Cy3-conjugated anti-mouse IgG (1:2000; Dianova), Alexa 350-conjugated anti-mouse IgG (1:500; Molecular Probes), or Cy3-conjugated anti-rat IgG (1:500; Dianova). Secondary antibodies were incubated for $1-2 \mathrm{hr}$ (room temperature). For nu-
Table 1. Primers used for single-cell RT-PCR

\begin{tabular}{|c|c|c|c|}
\hline Gene & Nucleotides & $\begin{array}{l}\text { Product } \\
\text { length (bp) }\end{array}$ & $\begin{array}{l}\text { Accession } \\
\text { number }\end{array}$ \\
\hline GLT-1 & se $452-475$; as $966-989$ & 538 & AB007810 \\
\hline GLT-1 (nested) & se $498-522$; as $882-905$ & 408 & \\
\hline GLAST & se $153-176$; as $780-798$ & 646 & AF330257 \\
\hline GLAST (nested) & se $203-222 ;$ as $622-638$ & 436 & \\
\hline EAAC1 & se $491-510$; as $888-910$ & 420 & D43797 \\
\hline EAAC1 (nested) & se $528-546 ;$ as $830-848$ & 321 & \\
\hline$\alpha 1-\alpha 4$ & $\begin{array}{c}\text { se } 1622-1646,1643-67,1652-1676 \\
1646-1670 ; \text { as } 2389-2413,2410- \\
2434,2425-2449,2413-2437\end{array}$ & $\begin{array}{l}\text { 792; } 798 \\
\text { (GluR3) }\end{array}$ & \\
\hline$\alpha 1$ (nested) & se $1717-1736$ & 632 & X57497 \\
\hline$\alpha 2$ (nested) & se $1742-1758$ & 628 & X57498 \\
\hline$\alpha 3$ (nested) & se $1755-1774$ & 630 & AB022342 \\
\hline$\alpha 4$ (nested) & se $1747-1765$ & 626 & AB022913 \\
\hline$\alpha 1-\alpha 4$ (nested) & $\begin{array}{l}\text { as } 2327-2348,2348-2369,2363- \\
\quad 2384,2351-2372\end{array}$ & & \\
\hline$\beta$-actin & se $10-30 ;$ as $375-396$ & 387 & X03672 \\
\hline$\beta$-actin (nested) & se $102-122$; as $323-339$ & 238 & \\
\hline
\end{tabular}

Position 1 is the first nucleotide of the initiation codon. "se" and "as" mark sense and antisense primers. The sense $\alpha 1-\alpha 4$ primer has one mismatch with $\alpha 1$ and two with $\alpha 3$; position 8 from $5^{\prime}$-end is $\mathrm{W}$; position 17 is $\mathrm{H}$. The antisense $\alpha 1-\alpha 4$ primer has one mismatch with $\alpha 2$ and two with $\alpha 4$; position 11 from $5^{\prime}$-end is B; position 14 is R. The nested antisense $\alpha 1-\alpha 4$ primer has one mismatch with $\alpha 1$. Primer sequences are available from gerald.seifert@ukb.uni-bonn.de.

clear counterstaining, Hoechst 33342 (Sigma) was used. Sections were mounted with Mowiol or mounting medium (Sigma) and analyzed with a confocal laser scanning microscope (CLSM) (Zeiss LSM 510 NLO, Axiovert 200, Zeiss, Göttingen, Germany, and Mira 900-F femtosecond mode-locked Ti:sapphire oscillator pumped by a $5 \mathrm{~W}$ Verdi solid-state frequency-doubled Nd:vanadate laser; Coherent, Dieburg, Germany). EGFP fluorescence was visualized using excitation at $488 \mathrm{~nm}$ and an emission bandpass filter of $500-530$ or $500-550 \mathrm{~nm}$; Cy3 was excited at $546 \mathrm{~nm}$ and emission monitored with a long-pass filter of $560 \mathrm{~nm}$; Oregon Green 514 was excited at $514 \mathrm{~nm}$ with emission monitored at bandpass $535-590 \mathrm{~nm}$; Alexa 350 was excited at $720 \mathrm{~nm}$ (two photon) and emission monitored with a bandpass filter of 435-485 nm. Alternatively, the tissue was inspected in a Zeiss Axiophot equipped with fluorescence optics. Images were taken with a digital SPOT camera and appropriate software (Diagnostic Instruments, Sterling Heights, MI), and immunoreactivity was quantitatively evaluated using MetaView software (Universal Imaging, West Chester, PA). Cell numbers were counted in 10 independent, scaled areas $(220 \times 170 \mu \mathrm{m})$ of different sections obtained from three animals. Specificity of immunoreactivity was controlled by incubation of tissue sections in dilution buffer instead of primary antibodies. No labeling in the CNS was observed under these conditions; however, unspecific staining of the meninges and connective tissue appeared in some cases.

\section{Single-cell reverse transcription- $P C R$}

RNA harvesting and reverse transcription. After recording, the cell content of isolated cells was harvested under microscopic control as reported previously (Seifert et al., 1997a). The pipette solution (6 $\mu \mathrm{l})$ was supplemented with $3 \mathrm{U}$ recombinant ribonuclease inhibitor (RNasin; Promega, Madison, WI). For single-strand cDNA synthesis, $3.5 \mu \mathrm{l}$ of reaction mix was added to the tubes (final volume $\sim 10 \mu \mathrm{l}$ ) containing reverse transcriptase buffer (Qiagen, Hilden, Germany), deoxyribonucleotide triphosphates (dNTPs, final concentration $4 \times 250 \mu \mathrm{M}$; Applied Biosystems, Weiterstadt, Germany), random hexanucleotide primer (50 $\mu \mathrm{M}$; Roche, Mannheim, Germany), $20 \mathrm{U}$ RNasin (Promega), and $0.5 \mu$ l Sensiscript reverse transcriptase (Qiagen). The reaction was performed at $37^{\circ} \mathrm{C}(1 \mathrm{hr})$.

Amplification of glutamate transporter cDNAs. A multiplex two-round single-cell PCR was performed with primers for glutamate transporter 1 (GLT-1), glutamate/aspartate transporter (GLAST), EAAC1, and $\beta$-actin (Table 1). The first PCR was performed after adding PCR buffer, $\operatorname{MgCl}_{2}(2.5$ $\mathrm{mm}$ ), and primers (200 nм each) to the reverse transcription product (final volume $50 \mu \mathrm{l}$ ). After denaturation, $3.5 \mathrm{U}$ Taq polymerase (Invitrogen, Karlsruhe, Germany) was added. Forty-five cycles were performed (denatur- 
ation at $94^{\circ} \mathrm{C}, 25 \mathrm{sec}$; annealing at $49^{\circ} \mathrm{C}, 2 \mathrm{~min}$ for the first five cycles, and $45 \mathrm{sec}$ for the remaining cycles; extension at $72^{\circ} \mathrm{C}, 25 \mathrm{sec}$; final elongation at $72^{\circ} \mathrm{C}, 7 \mathrm{~min}$ ). The $\mathrm{PCR}$ product was purified (Ultra clean DNA purification kit; Mobio, Solana Beach, CA), and an aliquot $(3 \mu \mathrm{l})$ was used as template for the second PCR ( 35 cycles; annealing at $54^{\circ} \mathrm{C}$, first five cycles: $2 \mathrm{~min}$, remaining cycles: $45 \mathrm{sec}$ ) using nested primers (Table 1). The conditions were the same as described for the first round, but dNTPs $(4 \times 50 \mu \mathrm{M})$ and Platinum Taq polymerase (2.5 U; Invitrogen) were added. Products were identified with gel electrophoresis using a molecular weight marker ( $\Phi X 174$ HincII digest; Eurogentec, Seraing, Belgium).

Amplification of GluR cDNAs. Transcript analysis was performed as described previously (Seifert et al., 1997a) with modifications. A multiplex PCR approach was performed, allowing the parallel amplification of the four AMPA receptor subunits and $\beta$-actin in the same individual cell. The reaction conditions were the same as described above, with the annealing temperatures in the second round being $51^{\circ} \mathrm{C}(\alpha 1, \alpha 4), 43^{\circ} \mathrm{C}(\alpha 2)$, and $57^{\circ} \mathrm{C}(\alpha 3$, $\beta$-actin).

Controls for reverse transcription and PCR amplification. Specificity of primers was tested with total RNA prepared from freshly isolated mouse brain (P20). For optimization, a tworound reverse transcription (RT)-PCR was performed with 2 ng of total RNA and primers as described above. Subsequent gel analysis did not detect unspecific products. The primers for different targets were located on different exons to prevent the amplification of genomic DNA. Omission of the reverse transcriptase or performing the RT-PCR reaction with bath solution served as negative controls and confirmed the specificity of the reaction.

\section{Data analysis}

Receptor desensitization was fitted by $I(t)=I_{\mathrm{ss}}+I_{0} \exp (-t / \tau)$, where $I_{\mathrm{SS}}$ is the steady-state current at $t=\infty, I_{0}$ is the maximal current, and $\tau$ is the time constant. The degree of receptor desensitization was defined by desensitization $\left.=100 \%\left[\left(I_{\text {peak }}-I_{\text {ss }}\right) / I_{\text {peak }}\right)\right]$, where $I_{\text {peak }}$ is the maximal receptor current, and $I_{\mathrm{SS}}$ is the steady-state current in the presence of the agonist determined $200 \mathrm{msec}$ after the application onset. Data are given as mean $\pm S D$. Differences were tested for significance using the Student's $t$ test $(p<0.05)$.

\section{Results}

Two populations of freshly isolated astroglial cells can be distinguished according to their EGFP fluorescence

Live cells were acutely isolated from hippocampus of $\mathrm{Tg}(\mathrm{GFAP} /$ EGFP) mice, and astrocytes were discerned by their green fluorescence caused by GFAP promoter-driven EGFP expression. To search for distinct subpopulations of astrocytes, cells were selected that differed in morphology and fluorescence intensity, and the corresponding patterns of membrane currents were compared. It was possible to distinguish two morphologically distinct cell types among the EGFP-labeled population. A first group of cells comprised pale, weakly fluorescent cells with short, thin processes. The whole-cell current pattern of these cells $(\mathrm{KCl}$ pipette solution) was dominated by outward $\mathrm{K}^{+}$currents, whereas background or inward $\mathrm{K}^{+}$currents $\left(I_{\text {Kir }}\right)$ were much less pronounced (resting potential $V_{\mathrm{r}}=-31 \pm 7 \mathrm{mV} ; n=34$ ) (Fig. 1A). In the presence of TTX, tail-current analysis found reversal po- tentials close to the $\mathrm{K}^{+}$equilibrium potential, indicating that the outward currents were mediated by $\mathrm{K}^{+}$(data not shown). Delayed rectifier $\left(I_{\mathrm{KD}}\right) \mathrm{K}^{+}$currents were separated from total outward currents by applying a predepolarization to $-40 \mathrm{mV}$ (300 $\mathrm{msec}$ ) before current activation. To isolate transient $\mathrm{K}^{+}$currents $\left(I_{\mathrm{KA}}\right)$, inactivation was removed (prepulse to $-110 \mathrm{mV}, 300$ $\mathrm{msec}$ ), test currents were activated, and $I_{\mathrm{KA}}$ was isolated from total outward currents by subtracting the current family obtained after the $-40 \mathrm{mV}$ prepulse at corresponding voltages. Most of these cells possessed TTX-sensitive $\mathrm{Na}^{+}$currents after depolarization beyond $-50 \mathrm{mV}$, but no action potentials were generated in the current clamp mode. The current phenotype of these cells did not change between P6 and P20 (Table 2).

A second type resembled protoplasmic astrocytes and was clearly distinguishable from the above mentioned by irregularly shaped somata bearing expanded, branched nets of processes and by intense, bright fluorescence (Fig. $1 B$ ). These cells displayed more negative resting potentials $\left(V_{\mathrm{r}}=-70 \pm 6 \mathrm{mV} ; n=78\right)$, a lower input resistance, and larger $C_{\mathrm{M}}$ values. In addition to residual $I_{\mathrm{KA}}$ and $I_{\mathrm{KD}}$ prominent background $\mathrm{K}^{+}$currents and $I_{\text {Kir }}$ prevailed in these cells, with the relative proportion of the latter significantly increasing during development (Table 2). Tail-current analysis found a reversal potential of $-72 \pm 3.7 \mathrm{mV}(n=22)$, confirming that the inward currents were mainly carried by $\mathrm{K}^{+}$.

\section{Weakly fluorescent cells express GluRs but not glutamate transporter currents}

We tested for the functional expression of AMPA-type GluRs and glutamate transporters in freshly isolated cells and selected the 
Table 2. Functional properties of freshly isolated EGFP-positive cells

\begin{tabular}{|c|c|c|c|c|c|c|}
\hline & Weakly fluore & & & Brightly fluore & d cells & \\
\hline & P6 (7) & P9 (13) & P18 (7) & P6 (15) & P9 (52) & P18 (22) \\
\hline$R_{\mathrm{i}}[\mathrm{G} \Omega]$ & $1.5 \pm 0.3$ & $1.5 \pm 0.7$ & $2 \pm 1$ & $0.5 \pm 0.2$ & $0.2 \pm 0.1^{*}$ & $0.1 \pm 0.05^{* *}$ \\
\hline$C_{m}[p F]$ & $6.8 \pm 2.3$ & $6.3 \pm 2.1$ & $5.1 \pm 0.9$ & $16.9 \pm 9.3$ & $16 \pm 11.4^{* * *}$ & $8.8 \pm 3.1^{* *}$ \\
\hline$g_{\text {Kir }} / g_{\text {out }}$ & $0.4 \pm 0.2$ & $0.4 \pm 0.2$ & $0.3 \pm 0.2$ & $1 \pm 0.4$ & $1.7 \pm 0.3^{*}$ & $2.2 \pm 0.3^{* *}$ \\
\hline$C D_{\mathrm{KA}}[\mathrm{pA} / \mathrm{pF}]$ & $201 \pm 105$ & $215 \pm 113$ & $168 \pm 57$ & $52.8 \pm 61.8$ & $41.8 \pm 55.9$ & $40.4 \pm 22.8$ \\
\hline$C D_{\text {Kir }}[\mathrm{pA} / \mathrm{pF}]$ & $11.9 \pm 6.6$ & $14.4 \pm 9.2$ & $7.7 \pm 5.7$ & $14.6 \pm 7.8$ & $51.3 \pm 49.7^{*}$ & $114 \pm 65^{* *}$ \\
\hline
\end{tabular}

Cell numbers are in parentheses. $C D_{\text {Kir }}$ and $g_{\text {Kir }}$ were determined at $-130 \mathrm{mV} ; C D_{\text {KA }}$ and $g_{\text {out }}$ were determined at +70 and $+20 \mathrm{mV}$, respectively (maximum currents). ${ }^{*}$ Significantly different from P6 and P18; ** significantly different from $\mathrm{P} 6$ and P9; *** significantly different from P18. CD, Current density.

A

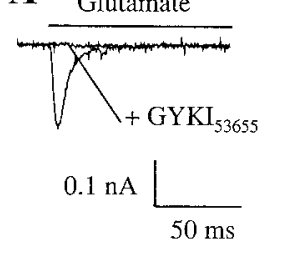

C

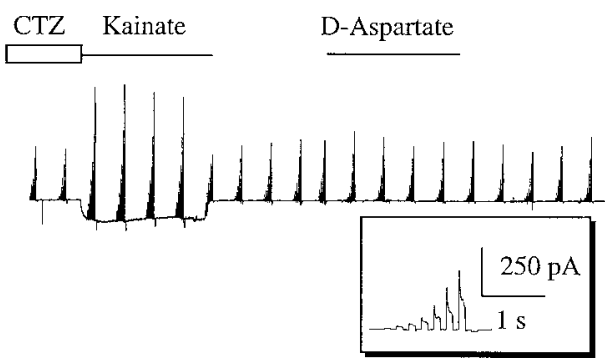

B

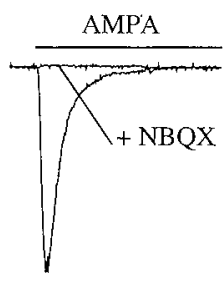

D-Aspartate

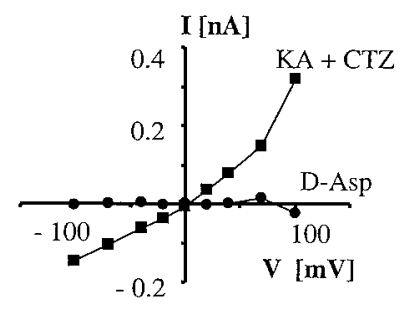

Figure 2. Weakly fluorescent acutely isolated cells express functional AMPA receptors but not glutamate transporters. $A$, In two different cells, rapid application of glutamate (left, P9) or AMPA (right, P15) evoked fast transient and completely desensitizing ( $\tau=6$ and $8.2 \mathrm{msec}$, respectively) inward currents that were fully inhibited by the AMPA receptor antagonist GYKI 53655 and NBQX. $B$, In another EGFP-positive cell (P13), the control response to glutamate (left) was enhanced twofold when the same cell was exposed to CTZ before application of the agonist (right). C, Membrane currents were elicited in a P13 cell by stepping the membrane between -100 and $+100 \mathrm{mV}$ for $100 \mathrm{msec}$ ( 100 msec intervals) in a bath solution containing $\mathrm{K}^{+}$channel blockers. The inset gives one current family at higher resolution. The cell displayed GluR currents after application of CTZ and kainate, whereas D-aspartate failed to evoke responses. The $I-V$ relationships (right) were calculated by subtracting current amplitudes at corresponding voltages in the presence of kainate or $D$-aspartate from the control currents recorded before application of the respective substance.

weakly fluorescent cells bearing few, thin processes. Fast application of glutamate or AMPA to these cells evoked rapidly activating and almost completely desensitizing currents (Fig. 2A,B). The peak responses $(-70 \mathrm{mV})$ induced by glutamate $(1 \mathrm{mM})$ and AMPA $(0.5$ $\mathrm{mM})$ amounted to $49 \pm 42.9 \mathrm{pA} / \mathrm{pF}(n=21)$ and $32.9 \pm 16.1 \mathrm{pA} / \mathrm{pF}$ $(n=7)$. We noted a significant increase in glutamate-evoked current densities between P6 and P20 (from $24.2 \pm 6.8$ to $71.6 \pm 28 \mathrm{pA} / \mathrm{pF}$ ), resembling developmental changes in nontransgenic mice (Seifert et al., 1997b). The glutamate-activated currents desensitized by $98.3 \pm$ $2.3 \%$ with the time constant being $\tau=8.1 \pm 1.9 \mathrm{msec}(n=20)$. Glutamate responses were sensitive to the AMPA-receptor modulator cyclothiazide (CTZ) (Partin et al., 1993) (0.1 mM; $n=4)$ (Fig. $2 B$ ) and were always completely blocked by 2,3-dihydroxy-6-nitro7-sulfamoyl-benzo(f)quinoxaline-2,3-dione (NBQX) (10 $\mu \mathrm{M} ; n=$ 7) or 1-(4-aminophenyl)-3-methylca rb a myl-4-methyl-3,4dihydro-7,8-methylenedioxy-5-H-2,3-benzodiazepine $\left(\mathrm{GYKI}_{53655}\right)$ $(50 \mu \mathrm{m} ; n=3)$ (Fig. 2A). Kainate ( $1 \mathrm{~mm})$ induced nondesensitizing currents $(15.3 \pm 4.4 \mathrm{pA} / \mathrm{pF},-70 \mathrm{mV} ; n=4)$ that were significantly enhanced when the cells were preincubated in CTZ $(0.1 \mathrm{~mm}$; increase to $720 \pm 210 \%)$. These findings (1) proved the presence of AMPA receptors and (2) indicated the absence of functional glutamate transporters. To obtain the $I-V$ relationships and prevent distortion of the responses by glial $\mathrm{K}^{+}$conductances, $\mathrm{BaCl}_{2}, 4-\mathrm{AP}$, and Even exposure to CTZ ( $0.1 \mathrm{~mm})$ before application of AMPA (1 $\mathrm{mM} ; n=3)$ or kainate ( $1 \mathrm{mM} ; n=4)$, which enhances AMPA receptor responses and allows detection of low levels of functional receptors, failed to disclose receptor currents (Fig. $3 A, B$ ). However, in the same cells, rapid application of glutamate activated transient inward currents, albeit with considerably smaller

amplitudes [ $1 \mathrm{~mm}: 7.9 \pm 4.5 \mathrm{pA} / \mathrm{pF}(n=11) ; 0.5 \mathrm{~mm}: 3.5 \pm 2.1$ $\mathrm{pA} / \mathrm{pF}(n=21) ;-70 \mathrm{mV}]$ and larger steady-state components as compared with the GluR cells (Fig. $3 A$ ). Current densities did not change within the developmental period investigated. The currents decayed by $67.2 \pm 5.3 \%$, following a single exponential with a time constant of $5.9 \pm 3.6 \mathrm{msec}(0.5 \mathrm{~mm},-70 \mathrm{mV} ; n=8)$. Neither the amplitudes nor the kinetics of the responses changed after pre-exposure of CTZ $(0.1 \mathrm{~mm} ; n=4)$ or coapplication of $\operatorname{NBQX}(10 \mu \mathrm{M} ; n=3)$ or $\mathrm{GYKI}_{53655}(50 \mu \mathrm{M} ; n=3)$. However, the currents were reversibly blocked by DL-threo-3-hydroxyaspartate (THA) (50 $\mu \mathrm{M} ; n=9$ ) (Fig. 3C), a transportable glutamate uptake inhibitor (Arriza et al., 1994). Fast application of D-aspartate $(0.5 \mathrm{~mm})$ evoked peak currents of $3.3 \pm 1.7 \mathrm{pA} / \mathrm{pF}$ that decayed with a time constant of $\tau=3.0 \pm 1.7 \mathrm{msec}(n=3)$. To reveal the $I-V$ relationship of the presumed transport currents, D-aspartate, which has a larger steady-state to peak current ratio than gluta- 
A
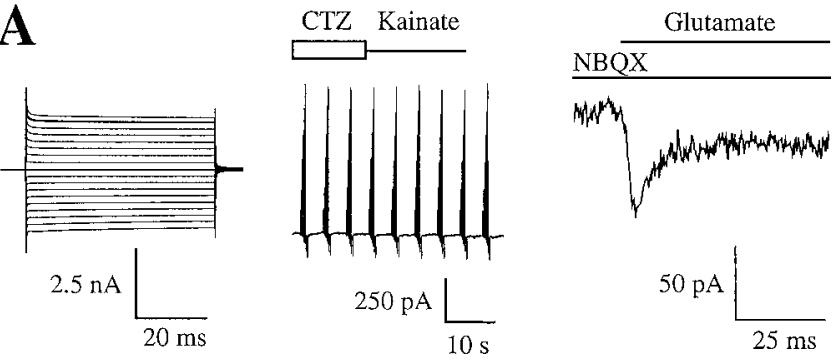

B

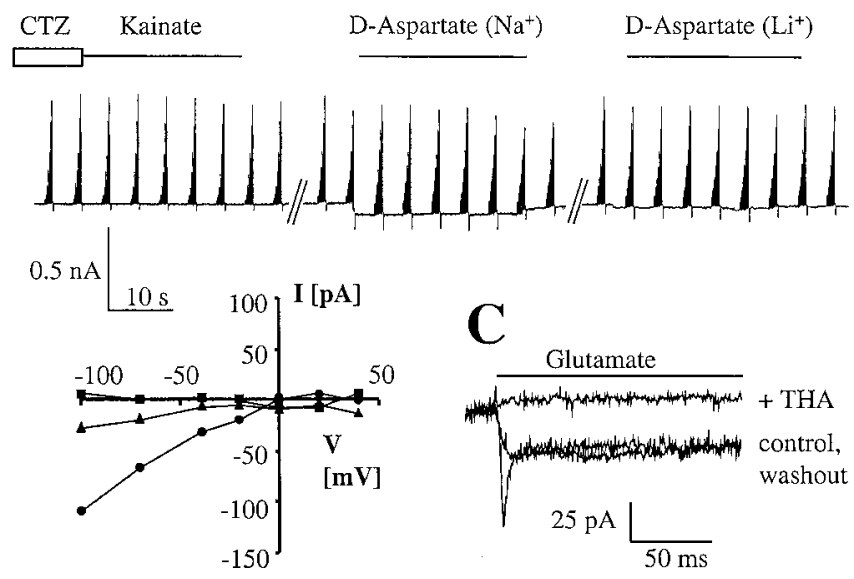

Figure 3. Brightly fluorescent, highly branched cells after acute isolation possess functional glutamate transporters but lack AMPA receptors. A, In an EGFP-positive cell at P14, prominent time- and voltage-independent currents were activated (left). Subsequent application of CTZ and kainate failed to evoke a response (for stimulation protocol, see legend to Fig. 20). However, inward currents were elicited in the same cell after fast application of glutamate (1 mM) in the presence of NBQX (right). $B$, Another example of the absence of coexpression of glutamate receptors and transporters. The cell (P11) did not respond to $C T Z$ and kainate, but inward currents were evoked by $\mathrm{D}$-aspartate, with the latter ceasing when $\mathrm{Na}^{+}$was replaced with $\mathrm{Li}^{+}$ in the bath solution. The bottom pane/ gives the respective $/-V$ relationships. $\mathrm{Na}^{+}$, circles; $\mathrm{Li}^{+}$, triangles; kainate/CTZ, squares. C, Fast application of glutamate $(0.5 \mathrm{~mm}$, duration $10 \mathrm{sec})$ to an EGFP-positive cell at P14 activated an inward current displaying an initial, rapidly decaying ( $\tau=3 \mathrm{msec}$ ) and a sustained component. Coapplication of THA led to a complete, partly reversible inhibition of the response.

mate (Arriza et al., 1994), was added to the bath while the membrane potential was stepped between -100 and $+50 \mathrm{mV}(n=9)$. The D-aspartate-evoked currents displayed (1) prominent inward rectification and (2) lack of reversal and (3) were strongly reduced after substitution of $\mathrm{Li}^{+}$for extracellular $\mathrm{Na}^{+}$, identifying these responses as transporter currents. To disclose a potential coexpression of GluRs, D-aspartate-responsive cells were subsequently exposed to AMPA ( 0.5 or $1 \mathrm{mM} n=8)$ or kainate/CTZ ( 1 and $0.1 \mathrm{~mm}$, respectively; $n=5$ ). These substances, however, failed to activate responses (Fig. $3 B$ ). Together, these findings suggested that the branched, brightly fluorescent cells expressed functional glutamate transporters but were devoid of AMPA or kainate receptors. Therefore, these astroglial cells were termed "GluT cells." We noticed that prolonged (several seconds) exposure of GluT cells to high concentrations $(0.5-1 \mathrm{mM})$ of glutamate led to a rapid rundown of the whole-cell responses, with the initial, transient component being particularly affected (Fig. 3C). This probably indicated intracellular accumulation of $\mathrm{Na}^{+}$or glutamate, or both, and a breakdown of the respective concentration gradients over the plasma membrane (Barbour et al., 1991).

In another subgroup of green fluorescent cells, morphologically resembling GluR cells, glutamate evoked neither GluR re- sponses nor uptake currents ("silent cells"; $16 \%$ of the weakly fluorescent cells with few processes). These cells were also essentially devoid of $I_{\text {Kir }}$ and background $\mathrm{K}^{+}$currents. Unlike GluR cells and GluT cells, the outward $\mathrm{K}^{+}$conductance declined at potentials between +40 and $+70 \mathrm{mV}$, producing a plateau region in the $I-V$ relationship (data not shown). Because of our focus on glutamate-responsive EGFP-positive cells, silent cells were not investigated in further detail.

The two populations of EGFP-positive cells can be recognized in acute slices from hippocampus

To confirm the presence of these two astroglial cell populations in brain tissue, acute slices were prepared to test whether the cells in situ matched the morphological classification of suspended cells. Indeed, many weakly fluorescent cells apparently bearing only a few short processes ( $41 \pm 12 \%$ of 336 EGFP-positive cells) could easily be detected in hippocampal slices, closely resembling GluR cells as studied in cell suspensions. Interestingly, intracellular loading with the fluorescence dye Texas Red uncovered an expanded net of thin processes emanating from the cell body, indicating that the intrinsic EGFP fluorescence of these cells was too low to allow visualization of their arborization (Fig. $4 A$ ) without increased gain settings of the green channel at the CLSM (compare Fig. 6). Recordings were obtained from cells in the CA1 stratum radiatum with a KSCN-based pipette solution to facilitate the identification of glutamate transporter currents (Eliasof and Jahr, 1996). Intracellular substitution of $\mathrm{Cl}^{-}$with $\mathrm{SCN}^{-}$in the presumed GluR cells led to the activation of a resting conductance (Fig. $4 B$ ) and a positive shift of the resting potential $\left(-48.0 \pm 14.3 \mathrm{mV}, n=21\right.$ vs $-61.1 \pm 16.2 \mathrm{mV}$ with $\mathrm{Cl}^{-}, n=$ $16)$, probably because of activation of an anion conductance. Outside-out patches were excised from these cells to investigate their glutamate responsiveness. Fast application of glutamate (1 $\mathrm{mm}$ ) to the patches activated rapid, transient responses (decay time constant $\tau=5.8 \pm 1.8 \mathrm{msec} ;-70 \mathrm{mV} ; n=21$ ) that almost completely desensitized. The currents were completely blocked by NBQX $(10 \mu \mathrm{M} ; n=3)$ and the glutamate ( $1 \mathrm{~mm})$-evoked $I-V$ relationships were linear with a reversal potential of $5.3 \pm 2.7 \mathrm{mV}$ (Fig. $4 B$ ). Thus, the cells in situ matched the properties of acutely isolated GluR cells.

The second, morphologically distinct cell type could easily be distinguished in the same hippocampal subregion in situ (36 \pm $12 \%$ of 336 cells). The somata as well as the extensive branching of the cells were brightly fluorescent, thus closely resembling the appearance of freshly isolated GluT cells. The morphology of these cells displayed the characteristics of bona fide protoplasmic astrocytes. In the whole-cell mode, depolarization and hyperpolarization activated prominent time- and voltage-independent outward and inward currents, whereas $I_{\mathrm{KA}}$ and $I_{\mathrm{KD}}$ were essentially absent (Fig. 4C), properties characterizing passive hippocampal astrocytes of nontransgenic mice (Steinhäuser et al., 1994a). Replacement of intracellular $\mathrm{Cl}^{-}$by $\mathrm{SCN}^{-}$significantly shifted the resting membrane potential toward more positive values $\left(-65.6 \pm 5.1 \mathrm{mV}, n=18\right.$, vs $-73.3 \pm 3.2 \mathrm{mV}$ with $\mathrm{Cl}^{-}, n=$ $10)$, possibly indicating a movement of $\mathrm{SCN}^{-}$through the transporter (Bergles and Jahr, 1997). Analysis of outside-out patches excised from the brightly fluorescent astrocytes in situ found an exclusive expression of functional glutamate transporters, whereas GluR currents were always absent. Fast application of glutamate $(1 \mathrm{mM})$ never produced outward currents at positive membrane potentials up to $+50 \mathrm{mV}$ (Fig. $4 C$, top right). At negative voltages, transient inward currents were observed $(-28.4 \pm$ $9.5 \mathrm{pA}$ ) that declined to a steady-state level with a time constant of 
A
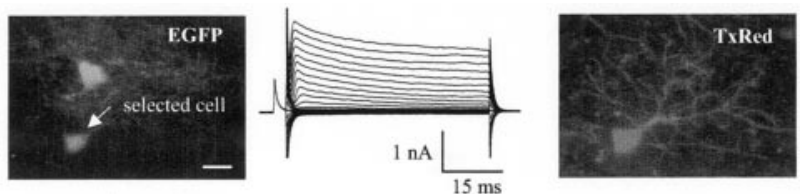

B

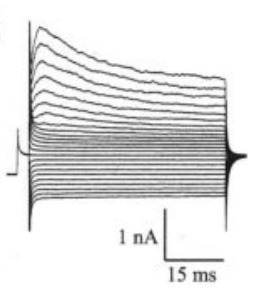

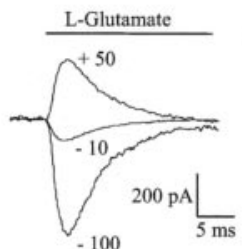
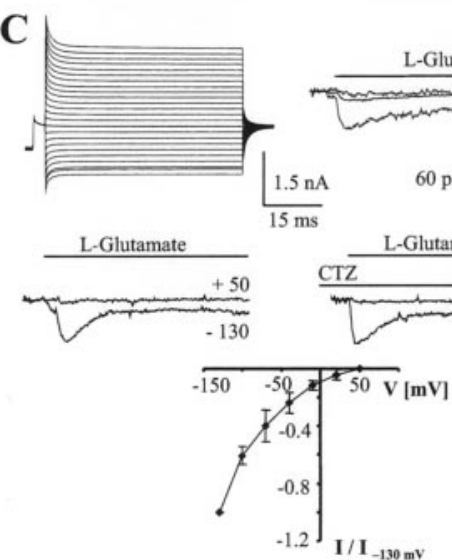

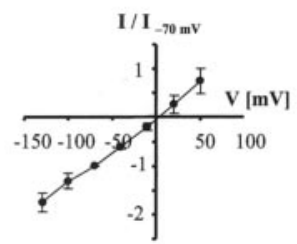

Figure 4. Properties of GluR cells and GluT cells in situ. A, Distinct intrinsic fluorescence of a GluT cell (top) and a GluR cell (arrow) in the CA1 stratum radiatum of a P12 mouse (left). Whole-cell currents were obtained from the GluR cell (see Fig. 1 for stimulation protocol, KCl-based pipette solution). During recording, the cell was filled with Texas Red-conjugated dextran, revealing thin, branched processes that were not visible in the EGFP image. Superposition of the fluorescence images demonstrated a close association of both astrocytes (right). B, Current pattern of another GluR cell (P12). Intracellular replacement of KCl with KSCN gave rise to a prominent resting conductance. Subsequently, an outside-out patch was excised from the cell, and glutamate was rapidly applied to the patch at different membrane potentials (top right). To get mean $I-V$ relationships, the responses of different cells $(n=10)$ were normalized to the respective peak amplitudes at $-70 \mathrm{mV}$ and averaged (bottom). C, A GluT cell (P18) was investigated as described in $B$. Note the absence of outward currents after glutamate application to the outside-out patch (top right). Even preapplication of (TZ to the patch failed to disclose any glutamate responses at positive voltages (middle). The $I-V$ curve gives mean values obtained from different GluT cells $(n=6)$ after normalizing to maximum currents at $-130 \mathrm{mV}$ (bottom).

$\tau=3.8 \pm 1.4 \mathrm{msec}(-130 \mathrm{mV} ; n=14)$ and were insensitive to CTZ $(n=4)$ (Fig. $4 C$, middle). $I-V$ analysis confirmed an inwardly rectifying conductance characteristic of glutamate transporters (Fig. 4C, bottom). To search for EGFP-positive cells that potentially coexpressed functional GluRs and glutamate transporters in situ, cells were selected that were hard to put unequivocally into one or the other category, i.e., branched cells with lower fluorescent intensity, and outside-out patches were recorded ( $n=15)$. Those cells proved to be GluT cells, GluR cells, or silent cells, with none of them coexpressing functional glutamate receptors and transporters.

In conclusion, analysis in situ confirmed the coexistence of two distinct types of EGFP-positive cells in the hippocampus that expressed either functional GluRs or glutamate transporters in a segregated, mutually exclusive manner.

\section{RT-PCR confirmed differences between the two cell populations on a transcript level}

Multiplex single-cell RT-PCR analysis was performed to clarify whether the two distinct cell types also differed at the transcript level. All GluR cells tested contained transcripts encoding the subunits GluR1-4, with a distribution similar to AMPA receptor-bearing nontransgenic astrocytes (Seifert et al., 1997a). This expression pattern was in clear contrast to the GluT cells, which were almost completely devoid of transcripts for any of the four GluR subunits. It should be mentioned that all of the GluR mRNA-negative cells were $\beta$-actin positive, confirming the specificity of the RT-PCR protocol (Fig. 5A).

All GluT cells expressed mRNAs encoding GLT-1 and GLAST. Interestingly, GLT-1 or GLAST transcripts, or both, were also

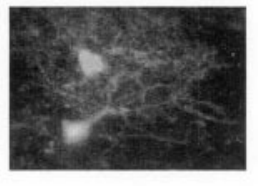

present in most of the GluR cells. Actually, $83 \%$ of these cells contained at least one of both transcripts, and among them, 73\% coexpressed GLT-1 and GLAST. Surprisingly, probing for mRNA of the neuronal glutamate transporter, EAAC1, was also successful in several (44\%) of the GluR cells, and these cells also contained GLT-1 and GLAST. In contrast, EAAC1 was never detected in the GluT cells (Fig. 5B). These findings demonstrated that in addition to their distinct functional properties, the two types of EGFP-positive cells also differed significantly in the respective gene expression pattern.

\section{Immunocytochemical analysis of GluR cells and GluT cells in situ}

For further identification of the EGFPpositive cells, antibody labeling against the astroglial markers, $\mathrm{S} 100 \beta$, and GFAP, together with Hoechst counterstaining, was performed. At $\mathrm{P} 14$, a total of $77 \pm 8 \%$ of the green fluorescent cells in the CA1 stratum radiatum $(n=349)$ were $\mathrm{S} 100 \beta$ positive. Moreover, $75 \pm 7 \%$ of the EGFPpositive cells $(n=397)$ were stained with GFAP antibodies. The staining pattern of S100 $\beta$ and GFAP did not overlap completely. We noted that almost all of the weakly EGFP-positive, presumed GluR cells $(97 \pm 5 \%)$ contained $\mathrm{S} 100 \beta(n=$ 96), whereas GFAP was expressed less frequently ( $48 \pm 28 \%$ of 57 cells) in these cells. Triple-fluorescence confocal analysis confirmed that virtually all of the EGFPpositive cells expressed at least one of the two astrocyte marker proteins. $S 100 \beta$ was located primarily to the somata, whereas GFAP delineated the glial processes (Fig. $6 A-D$ ). Many EGFPpositive cells were found to coexpress $S 100 \beta$ and GFAP, matching findings in nontransgenic animals (Kukley et al., 2001) and identifying these cells as astrocytes.

A second series of confocal imaging used double labeling against $S 100 \beta$ and AN2 (Niehaus et al., 1999), the mouse homolog of NG2. Surprisingly, in approximately one-third of the green fluorescent cells, AN2/NG2 and $\mathrm{S} 100 \beta$ were coexpressed $(n=41 / 109 ; 38 \%)$ (Fig. 6E,F). These cells represented a subpopulation of the GluR cells described above, whereas GluT cells were always AN2/NG2 negative; $41 \%(n=53$ of 130$)$ of the S100 $\beta$-positive cells were AN2 positive, and $21 \%(n=14$ of 67$)$ of AN2-positive cells lacked the GFAP/EGFP transgene.

\section{Discussion}

Astrocytes in the hippocampus display different functional properties

Previous analysis has found that astrocytes in the hippocampus are heterogeneous with regard to their functional properties. Depolarization and hyperpolarization activated different patterns of whole-cell $\mathrm{Na}^{+}$and $\mathrm{K}^{+}$currents in astrocytes in situ, which led to a rough differentiation between "complex" and "passive cells" (Steinhäuser et al., 1994a). Investigation of acutely isolated cells confirmed the existence of astrocytes with such qualitatively different current phenotypes (Tse et al., 1992; Steinhäuser et al., 1994b; Seifert and Steinhäuser, 1995; Zhou and Kimelberg, 2000) 
and excluded that the observations in situ reflected technical artifacts. Moreover, earlier work in the hippocampus found astrocytes with a different glutamate responsiveness: cells that expressed functional GluRs (AMPA type) but lacked glutamate uptake currents (Seifert and Steinhäuser, 1995; Seifert et al., 1997b; Zhou and Kimelberg, 2001) and cells that possessed significant glutamate transport currents (Bergles and Jahr, 1997, 1998; Zhou and Kimelberg, 2001).

\section{Tg(GFAP/EGFP) mice allow}

identification of morphologically and functionally distinct astroglial cell types Usage of $\operatorname{Tg}($ GFAP/EGFP) mice allowed the identification of living astrocytes, and subsequent immunostaining located S100 $\beta$ and GFAP in almost all of the green fluorescent cells. Two main groups of EGFP-positive cells were identified in the hippocampus that displayed distinct morphological and functional properties. Both groups are astroglial with respect to expression of $\mathrm{S} 100 \beta$ and GFAP/EGFP transgene activity. On the basis of their contrasting sensitivity to glutamate, the two types were designated as GluR cells and GluT cells. The weakly green fluorescent GluR cells closely matched the AMPA receptor-bearing astrocytes in the hippocampus of nontransgenic mice described previously as complex cells (Seifert and Steinhäuser, 1995; Seifert et al., 1997b). They possessed ionotropic GluRs of the AMPA subtype, voltage-dependent outward $\mathrm{K}^{+}$currents, and negligible inward rectification, and virtually all expressed $\mathrm{S} 100 \beta$, a $\mathrm{Ca}^{2+}$-binding protein identifying gray matter astrocytes (Barger et al., 1992). The properties of these cells were clearly different from the brightly fluorescent, highly branched GluT cells, which displayed glutamate uptake currents and prominent $I_{\mathrm{Kir}}$ and background $\mathrm{K}^{+}$currents and belong to the described passive cells.

Our finding that GluR cells express functional GluRs but no glutamate uptake currents agrees with earlier work (Seifert and Steinhäuser, 1995; Seifert et al., 1997b; Zhou and Kimelberg, 2001). However, we noticed that in situ an expanded net of fine processes emanating from the somata was disclosed by Texas Red filling or enhanced gain settings at the CLSM and that in several GluR cells transporter transcripts were identified by RT-PCR. This leaves us with the possibility that functional transporters selectively localized at distant processes have been overlooked in single-cell preparations, be-
A
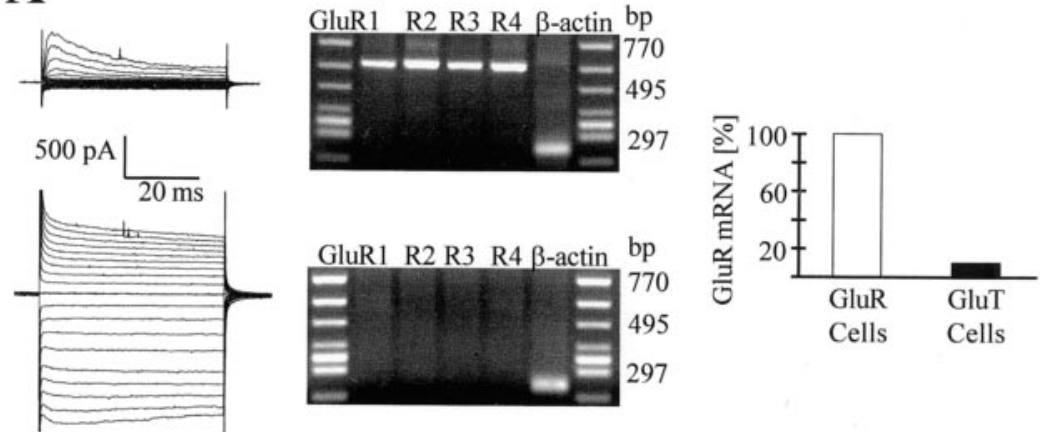

B
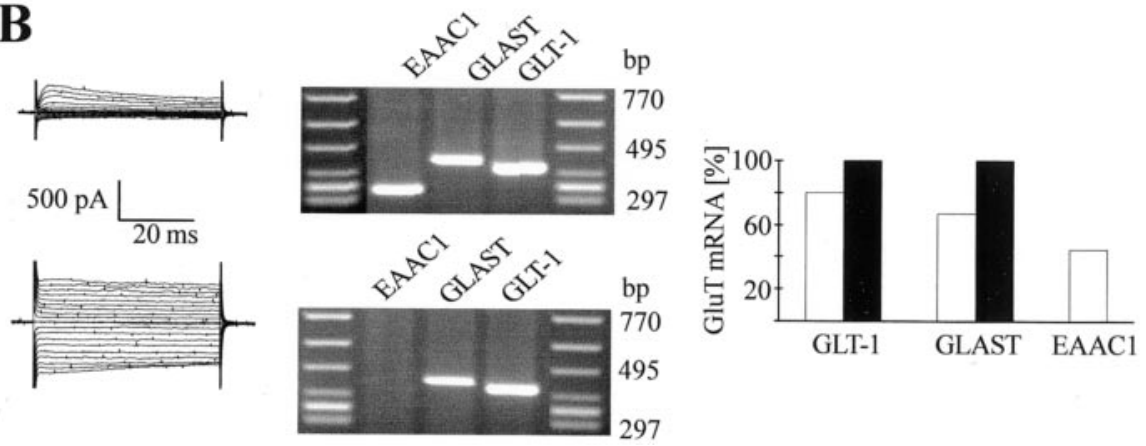

Figure 5. Segregated expression of AMPA receptor and glutamate transporter transcripts by individual acutely isolated EGFPpositive cells. A, Presumed GluR cells and GluT cells were selected under fluorescence illumination, and membrane currents were activated as described in Figure 3 A. After recording, the cytoplasm was harvested for RT-PCR. The GluR cell (top) contained mRNAs for all four GluR subunits, whereas only the housekeeping gene was detected in the GluT cell (middle). The bar graph (bottom) gives the frequency of GluR mRNA detection in both cell types (GluR cells, $n=6$; GluT cells, $n=10$ ). B, Both cell types were tested for the expression of transporter transcripts. A coexpression of EAAC1, GLAST, and GLT-1 was found in a GluR cell (top). The GluT cell (middle) contained mRNAs encoding GLAST and GLT-1. The bar graph (bottom) summarizes the distribution of transporter RNAs in the two cell types. The GluT cells ( $n=17$ ) (filled bars) all coexpressed GLAST and GLT-1, whereas only a partial overlap of both transcripts was observed in the GluR cells $(n=18)$ (open bars). Some of the GluR cells ( 4 of 9$)$ also contained mRNA for EAAC1, whereas this transcript was absent in GluT cells $(n=10)$.
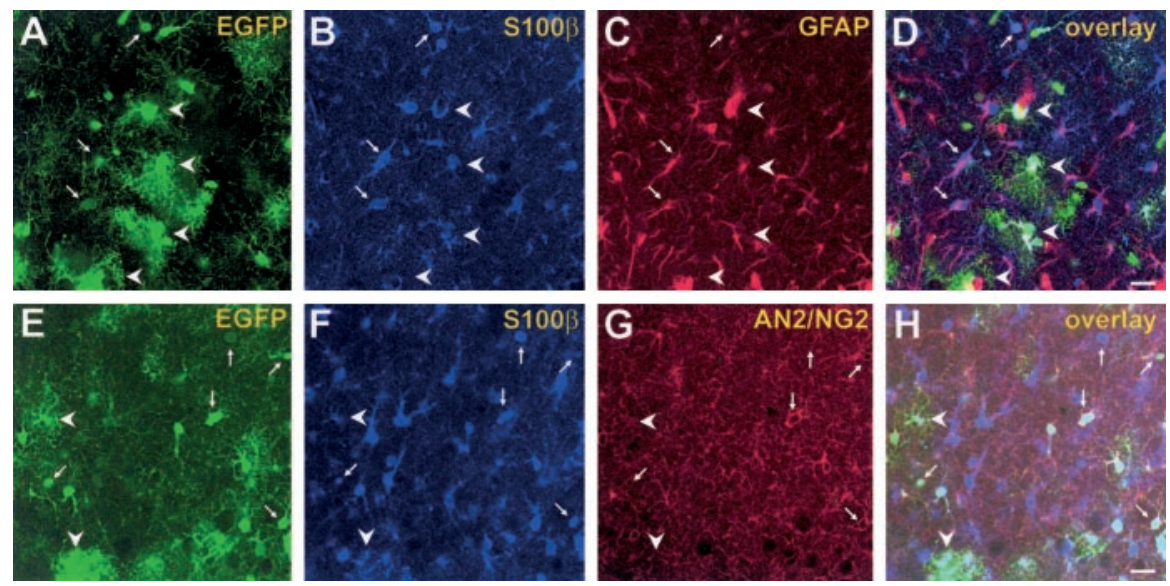

Figure 6. Morphologically and immunohistochemically distinct populations of EGFP-positive cells can be distinguished in the CA1 stratum radiatum of Tg(GFAP/EGFP) mice (P10). A-D, Triple-fluorescence analysis, using intrinsic EGFP fluorescence ( $g r e e n)$ and double-immunolabeling against $S 100 \beta$ (blue) and GFAP (red). Arrows indicate weakly EGFP fluorescent, GluR cells expressing GFAP and S100 $\beta$. Arrowheads mark S100 $\beta$ - and GFAP-positive astrocytes with high levels of EGFP resembling GluT cells. E-H, Triple-fluorescence analysis with intrinsic EGFP fluorescence ( $g r e e n)$ and double-immunolabeling against $\mathrm{S} 100 \beta$ (blue) and AN2 (red). Arrows mark putative GluR cells with fewer processes that express EGFP, S100 $\beta$, and AN2. Arrowheads indicate highly branched, EGFP-and S100 $\beta$-positive cells lacking AN2 immunoreactivity. Note that the fluorescence intensities of GluR cell somata (arrows) saturate the green CLSM channel. The gain settings were increased to visualize thin processes with low EGFP expression. Scale bar, $20 \mu \mathrm{m}$. 
cause processes have been ripped off during the isolation procedure and in situ recordings were confined to patches excised from cell bodies only. However, this explanation appears unlikely because the loss of branching during isolation varied considerably from cell to cell, which would lead us to expect at least residual responses in some cells. In addition, such an explanation would infer a completely different distribution of these proteins in the GluT cells in which the same methodical limitations did not hinder detection of uptake currents.

There is a controversy in the literature regarding whether hippocampal astrocytes with glutamate transporters coexpress functional AMPA receptors (Bergles and Jahr, 1997; Zhou and Kimelberg, 2001), as has been demonstrated in Bergman glial cells (Bergles et al., 1997; Clark and Barbour, 1997). Our data clearly argue against this possibility and corroborate findings of Bergles and Jahr (1997). Under conditions that enhanced potential GluR currents, thus allowing unequivocal distinction from glutamate uptake, none of the GluT cells in the developing hippocampus were found to coexpress functional GluRs. To exclude the possibility that the findings in freshly isolated cells were obscured by enzymatic treatment, comparative investigations were performed in situ that led to the same conclusions.

\section{Transcript analysis and immunocytochemistry corroborate the existence of discrete populations of EGFP-positive cells} The functional data received clear-cut confirmation from singlecell RT-PCR, showing that the GluT cells lacked the receptors even at the transcript level. Both EGFP-positive cell types expressed transcripts for GLAST or GLT-1, or both. However, $\sim 50 \%$ of the GluR cells tested, but none of the GluT cells, also contained mRNA encoding EAAC1. This glutamate transporter was assumed to be expressed solely by neurons (for review, see Danbolt, 2001), but a recent study has found EAAC1 also in some presumed gray matter astrocytes (Conti et al., 1998).

Antibody labeling confirmed the presence of the astroglial markers, GFAP and S100 $\beta$, in the vast majority of the EGFPpositive cells. The morphological, immunocytochemical, and functional characteristics of the GluT cells define them as protoplasmic astrocytes. Obviously, the GluR cells are more heterogeneous. Approximately $50 \%$ of the GluR cells coexpressed S100 $\beta$ and GFAP, confirming their astroglial identity. However, not all of the GluR cells matched "classical” astroglial properties. A considerable amount of the GluR cells expressed transcripts encoding a neuronal glutamate transporter. Moreover, a subpopulation of the EGFP/S100 $\beta$-positive GluR cells expressed AN2/NG2, which has been regarded as a marker of oligodendroglial progenitor cells (Ong and Levine, 1999). Interestingly, a recent study using mice in which oligodendrocytes were labeled by proteolipid protein (PLP) promoter-driven EGFP expression revealed two distinct NG2-positive cell populations, a PLP/EGFP-positive population and a PLP/EGFP-negative population (Mallon et al., 2002). The latter population might well include the EGFP/NG2positive cells described in the present study.

Our findings strongly suggest that GluR and GluT cells comprise distinct cell types. First, the $\mathrm{K}^{+}$current pattern of GluR cells remained unchanged during early postnatal development. Obviously, they did not adopt the current phenotype of GluT cells, which underwent a significant upregulation of inward rectification during the same period. Second, not a single green fluorescent cell coexpressed functional GluRs and glutamate transporters, although the experiments were conducted between P6 and P20, a time window characterized by significant alterations of the structural and functional phenotypes of developing hippocampal astrocytes (Nixdorf-Bergweiler et al., 1994; Kressin et al., 1995). Similar to findings in wild-type mice (Seifert et al., 1997b), the amplitude of GluR responses of GluR cells increased with proceeding maturation, whereas the uptake currents of GluT cells remained unchanged. In addition, GluR cells differed from GluT cells in the expression of transcripts for EAAC1 and AN2/NG2 protein. These data clearly argue against the notion that glutamate transporters replace GluRs with progressing cellular maturation. Together, our results do not support the hypothesis that GluT cells represent the final, mature stage of GluR cells but demonstrate the coexistence of functionally and morphologically distinct astrocyte cell types in a given brain area.

\section{Functional considerations}

Usage of $\mathrm{Tg}$ (GFAP/EGFP) mice enabled us to systematically investigate morphologically different types of presumed astrocytes in situ, revealing that these cells comprise a much larger functional heterogeneity than suggested hitherto. The properties of the GluT cells are in line with the classical view of protoplasmic astrocytes as a sink for synaptically released glutamate (Anderson and Swanson, 2000). Obviously, the GluR cells serve other functions. Many of the GluR cells expressed the astroglial markers S100 $\beta$ and GFAP. However, the present data suggest that GluR cells also include NG2-positive glial cells, which have been shown to receive direct glutamatergic input from CA3 neurons (Bergles et al., 2000). The efficiency of this input might vary during early postnatal development when splicing and subunit assembly of AMPA receptors in GluR cells undergo considerable changes (Seifert et al., 2003).

In addition, on the basis of their low EGFP and GFAP levels and the presence of transcripts encoding glial and neuronal glutamate transporters, it is tempting to speculate that at least some of the GluR cells represent an intermediate cell type, i.e., "astron"-like, transient cells that still possess glial properties but have already switched on the expression of neuronal genes. Indeed, remaining GFP signal has been observed in glia-derived neurons in the embryonic cortex of $\mathrm{Tg}(\mathrm{GFAP} / \mathrm{GFP})$ mice (Malatesta et al., 2000). The CA1 region of adult mouse hippocampus still contains mitotically active cells (Rietze et al., 2000). Future work has to reveal whether such GluR cells include the transient, astrocyte-derived cells that function as precursors in the formation of new hippocampal neurons (Seri et al., 2001).

\section{References}

Akopian G, Kuprijanova E, Kressin K, Steinhäuser C (1997) Analysis of ion channel expression by astrocytes in red nucleus brain stem slices of the rat. Glia 19:234-246.

Anderson CM, Swanson RA (2000) Astrocyte glutamate transport: review of properties, regulation, and physiological functions. Glia 32:1-14.

Araque A, Sanzgiri RP, Parpura V, Haydon PG (1998) Calcium elevation in astrocytes causes an NMDA receptor-dependent increase in the frequency of miniature synaptic currents in cultured hippocampal neurons. J Neurosci 18:6822-6829.

Arriza JL, Fairman WA, Wadiche JI, Murdoch GH, Kavanaugh MP, Amara SG (1994) Functional comparisons of three glutamate transporter subtypes cloned from human motor cortex. J Neurosci 14:5559-5569.

Barbour B, Brew H, Attwell D (1991) Electrogenic uptake of glutamate and aspartate into glial cells isolated from the salamander(ambystoma) retina. J Physiol (Lond) 436:169-193.

Barger SW, Wolchok SR, van Eldik LJ (1992) Disulfide-linked S100 $\beta$ dimers and signal transduction. Biochem Biophys Acta 1160:105-112.

Bergles DE, Jahr CE (1997) Synaptic activation of glutamate transporters in hippocampal astrocytes. Neuron 19:1297-1308.

Bergles DE, Jahr CE (1998) Glial contribution to glutamate uptake at Schaffer collateral-commissural synapses in the hippocampus. J Neurosci 18:7709-7716. 
Bergles DE, Dzubay JA, Jahr CE (1997) Glutamate transporter currents in Bergmann glial cells follow the time course of extrasynaptic glutamate. Proc Natl Acad Sci USA 94:14821-14825.

Bergles DE, Roberts JD, Somogyi P, Jahr CE (2000) Glutamatergic synapses on oligodendrocyte precursor cells in the hippocampus. Nature 405:187-191.

Bezzi P, Carmignoto G, Pasti L, Vesce S, Rossi D, Rizzini BL, Pozzan T, Volterra A (1998) Prostaglandins stimulate calcium-dependent glutamate release in astrocytes. Nature 391:281-285.

Brenner M, Messing A (1996) GFAP transgenic mice. Methods 10:351-364.

Chvátal A, Pastor A, Mauch M, Syková E, Kettenmann H (1995) Distinct populations of identified glial cells in the developing rat spinal cord slice: ion channel properties and cell morphology. Eur J Neurosci 7:129-142.

Clark BA, Barbour B (1997) Currents evoked in Bergmann glial cells by parallel fibre stimulation in rat cerebellar slices. J Physiol (Lond) 502:335-350.

Colquhoun D, Jonas P, Sakmann B (1992) Action of brief pulses of glutamate on AMPA/kainate receptors in patches from different neurones of rat hippocampal slices. J Physiol (Lond) 458:261-287.

Conti F, DeBiasi S, Minelli A, Rothstein JD, Melone M (1998) EAAC1, a high-affinity glutamate transporter, is localized to astrocytes and GABAergic neurons besides pyramidal cells in the rat cerebral cortex. Cereb Cortex 8:108-116.

Danbolt NC (2001) Glutamate uptake. Prog Neurobiol 65:1-105.

Diers-Fenger M, Kirchhoff F, Kettenmann H, Levine JM, Trotter J (2001) AN2/NG2 protein-expressing glial progenitor cells in the murine CNS: isolation, differentiation, and association with radial glia. Glia $34: 213-228$

Eliasof S, Jahr CE (1996) Retinal glial cell glutamate transporter is coupled to an anionic conductance. Proc Natl Acad Sci USA 93:4153-4158.

Grosche J, Matyash V, Moller T, Verkhratsky A, Reichenbach A, Kettenmann H (1999) Microdomains for neuron-glia interaction: parallel fiber signaling to Bergmann glial cells. Nat Neurosci 2:139-143.

Haydon PG (2001) Glia: listening and talking to the synapse. Nat Rev Neurosci 2:185-193.

Kang J, Jiang L, Goldman SA, Nedergaard M (1998) Astrocyte-mediated potentiation of inhibitory synaptic transmission. Nat Neurosci 1:683-692.

Kressin K, Kuprijanova E, Jabs R, Seifert G, Steinhäuser C (1995) Developmental regulation of $\mathrm{Na}^{+}$and $\mathrm{K}^{+}$conductances in glial cells of mouse hippocampal brain slices. Glia 15:173-187.

Kukley M, Barden JA, Steinhäuser C, Jabs R (2001) Distribution of P2X receptors on astrocytes in juvenile rat hippocampus. Glia 36:11-21.

Malatesta P, Hartfuss E, Gotz M (2000) Isolation of radial glial cells by fluorescent-activated cell sorting reveals a neuronal lineage. Development 127:5253-5263.

Mallon BS, Shick HE, Kidd GJ, Macklin WB (2002) Proteolipid promoter activity distinguishes two populations of NG2-positive cells throughout neonatal cortical development. J Neurosci 22:876-885.

Newman EA, Zahs KR (1998) Modulation of neuronal activity by glial cells in the retina. J Neurosci 18:4022-4028.

Niehaus A, Stegmuller J, Diers-Fenger M, Trotter J (1999) Cell-surface glycoprotein of oligodendrocyte progenitors involved in migration. J Neurosci 19:4948-4961.

Nixdorf-Bergweiler BE, Albrecht D, Heinemann U (1994) Developmental changes in the number, size, and orientation of GFAP-positive cells in the CA1 region of rat hippocampus. Glia 12:180-195.

Nolte C, Matyash M, Pivneva T, Schipke CG, Ohlemeyer C, Hanisch UK, Kirchhoff F, Kettenmann H (2001) GFAP promoter-controlled EGFPexpressing transgenic mice: a tool to visualize astrocytes and astrogliosis in living brain tissue. Glia 33:72-86.
Ong WY, Levine JM (1999) A light and electron microscopic study of NG2 chondroitin sulfate proteoglycan-positive oligodendrocyte precursor cells in the normal and kainate-lesioned rat hippocampus. Neuroscience 92:83-95.

Partin KM, Patneau DK, Winters CA, Mayer ML, Buonanno A (1993) Selective modulation of desensitization at AMPA versus kainate receptors by cyclothiazide and concanavalin A. Neuron 11:1069-1082.

Porter JT, McCarthy KD (1996) Hippocampal astrocytes in situ respond to glutamate released from synaptic terminals. J Neurosci 16:5073-5081.

Rietze R, Poulin P, Weiss S (2000) Mitotically active cells that generate neurons and astrocytes are present in multiple regions of the adult mouse hippocampus. J Comp Neurol 424:397-408.

Schröder W, Seifert G, Hüttmann K, Hinterkeuser S, Steinhäuser C (2002) AMPA receptor-mediated modulation of inward rectifier $\mathrm{K}^{+}$channels in astrocytes of mouse hippocampus. Mol Cell Neurosci 19:447-458.

Seifert G, Steinhäuser C (1995) Glial cells in the mouse hippocampus express AMPA receptors with an intermediate $\mathrm{Ca}^{2+}$ permeability. Eur J Neurosci 7:1872-1881.

Seifert G, Rehn L, Weber M, Steinhäuser C (1997a) AMPA receptor subunits expressed by single astrocytes in the juvenile mouse hippocampus. Mol Brain Res 47:286-294.

Seifert G, Zhou M, Steinhäuser C (1997b) Analysis of AMPA receptor properties during postnatal development of mouse hippocampal astrocytes. J Neurophysiol 78:2916-2923.

Seifert G, Weber M, Schramm J, Steinhäuser C (2003) Changes in splice variant expression and subunit assembly of AMPA receptors during maturation of hippocampal astrocytes. Mol Cell Neurosci, in press.

Seri B, Garcia-Verdugo JM, McEwen BS, Alvarez-Buylla A (2001) Astrocytes give rise to new neurons in the adult mammalian hippocampus. J Neurosci 21:7153-7160.

Steinhäuser C, Gallo V (1996) News on glutamate receptors in glial cells. Trends Neurosci 19:339-345.

Steinhäuser C, Berger T, Frotscher M, Kettenmann H (1992) Heterogeneity in the membrane current pattern of identified glial cells in the hippocampal slice. Eur J Neurosci 4:472-484.

Steinhäuser C, Jabs R, Kettenmann H (1994a) Properties of GABA and glutamate responses in identified glial cells of the mouse hippocampal slice. Hippocampus 4:19-36.

Steinhäuser C, Kressin K, Kuprijanova E, Weber M, Seifert G (1994b) Properties of voltage-activated sodium and potassium currents in mouse hippocampal glial cells in situ and after acute isolation from tissue slices. Pflügers Arch 428:610-620.

Tse FW, Fraser DD, Duffy S, MacVicar BA (1992) Voltage-activated $\mathrm{K}^{+}$ currents in acutely isolated hippocampal astrocytes. J Neurosci 12:1781-1788.

Verkhratsky A, Steinhäuser C (2000) Ion channels in glial cells. Brain Res Rev 32:380-412.

Verkhratsky A, Orkand RK, Kettenmann H (1998) Glial calcium: homeostasis and signaling function. Physiol Rev 78:99-141.

Walz W (2000) Controversy surrounding the existence of discrete functional classes of astrocytes in adult gray matter. Glia 31:95-103.

Zawar C, Plant TD, Schirra C, Konnerth A, Neumcke B (1999) Cell-type specific expression of ATP-sensitive potassium channels in the rat hippocampus. J Physiol (Lond) 514 2:327-341.

Zhou M, Kimelberg HK (2000) Freshly isolated astrocytes from rat hippocampus show two distinct current patterns and different $\left[\mathrm{K}^{+}\right]_{\mathrm{o}}$ uptake capabilities. J Neurophysiol 84:2746-2757.

Zhou M, Kimelberg HK (2001) Freshly isolated hippocampal CA1 astrocytes comprise two populations differing in glutamate transporter and AMPA receptor expression. J Neurosci 21:7901-7908. 